Article

\title{
Experimental Staphylococcus aureus Mastitis Infection Model by Teat Dipping in Bacterial Culture Suspension in Dairy Cows
}

\author{
Oudessa Kerro Dego ${ }^{1, *}$, Paulina A. Pacha ${ }^{1,2,3}$ ㄹ, Barbara E. Gillespie ${ }^{1}$ and Gina M. Pighetti ${ }^{1}$ \\ 1 Department of Animal Science, Knoxville, The University of Tennessee, TN 37996, USA; \\ ppacha@santotomas.cl (P.A.P.); bgillesp@utk.edu (B.E.G.); pighetti@utk.edu (G.M.P.) \\ 2 Facultad de Ciencias Veterinarias, Universidad de Concepción, Chillan 370000, Chile \\ 3 Escuela de Medicina Veterinaria, Facultad de Ciencias Veterinariasy Recursos Renovables, \\ Universidad Santo Tomás, Temuco 4780000, Chile \\ * Correspondence: okerrode@utk.edu; Tel.: +01-865-974-9740
}

Received: 24 March 2020; Accepted: 22 April 2020; Published: 25 April 2020

Simple Summary: Udder infection by bacteria such as Staphylococcus aureus cause economic losses to dairy production. An effective vaccine is required to control S. aureus mastitis. To develop an effective vaccine, a good experimental infection model is required. Infusion of bacteria into the udder can overwhelm the host because it bypasses physical barriers and defense mechanisms in the teat canal. The objective of this study was to develop Staphylococcus aureus mastitis challenge model that mimics natural infection. Eight Holstein dairy cows within 1st to 3rd parity at early non-milking period were randomly divided into experimental $(n=5)$ and control $(n=3)$ groups. All teats of experimental cows were challenged by dipping into $S$. aureus culture suspension, whereas those of control cows were dipped into phosphate-buffered saline. Bacteria in the mammary secretion was determined by bacteriological culture. The antibody titer in blood was tested by enzyme-linked immunosorbent assay (ELISA). Other analyses, which include somatic cell count, rectal body temperature, inflammatory changes in mammary secretion, and gland tissues, were assessed. Results showed that three and one of five experimental cows developed subclinical and clinical mastitis, respectively. The remaining cow was infected with Staphylococcus chromogenes. In conclusion, experimental S. aureus mastitis can be induced by teat dipping in the bacterial culture.

Abstract: Mastitis is inflammation of mammary glands usually caused by bacteria such as Staphylococcus aureus. Dairy cows are susceptible to mastitis during early dry and transition periods. Effective vaccine is needed during these periods. One of the limitations to develop an effective vaccine against $S$. aureus is the absence of good infection model. Intramammary infusion (IMIF) with S. aureus has been used as an infection model to test vaccine efficacy. IMIF is reliable in causing mastitis, but it bypasses physical barriers, non-specific natural defenses, and immunity in the teat canal. IMIF also transfers a large number of bacteria into the intramammary area at once. The objective of this study was to develop S. aureus IMIF model that mimics natural infection. Eight Holstein dairy cows were randomly divided into two groups of experimental $(n=5)$ and control $(n=3)$ cows. All teats of experimental cows were dipped in S. aureus culture suspension, whereas that of control cows were dipped in phosphate-buffered saline. Results showed that four of five cows were infected with challenge strain by day 3 of the challenge. The remaining cow was infected with Staphylococcus chromogenes. In conclusion, an experimental S. aureus intramammary infection can be induced by teat dipping into bacterial suspension.

Keywords: experimental infection; Staphylococcus aureus; bovine mastitis; intramammary infection model; teat dipping; bacterial culture suspension 


\section{Introduction}

Staphylococcal mastitis is a major cause of economic losses in dairy production worldwide [1,2]. Coagulase positive Staphylococcus aureus is one of the most common contagious mastitis pathogens in dairy cows, with an estimated incidence rate of 43-74\% [3,4]. More recently, coagulase-negative Staphylococcus species (CNS) such as S. chromogenes, S. simulans, S. xylosus, S. haemolyticus, S. hyicus and S. epidermidis are increasingly isolated from bovine milk [5-8] with $S$. chromogenes being the most increasingly diagnosed causative agent of subclinical mastitis. Staphylococcus chromogenes [9] and other CNS [10], have been shown to cause subclinical infections in dairy cows that reduced the prevalence of contagious mastitis pathogens.

Dairy cows are susceptible to mastitis during early dry period and transition (3 weeks before parturition and 3 weeks after parturition) or periparturient periods [11,12] with S. aureus being reported as a major pathogen [13]. Current mastitis control measures are based on milking hygiene; use of properly functioning milking machines; maintaining clean, dry, comfortable housing areas; good nutritional programs; segregation and culling of persistently infected animals; dry cow antibiotic therapy; and proper identification and treatment of cows with clinical and subclinical mastitis. When fully adopted and applied; these measures are known to reduce incidence rates of contagious mastitis pathogens including S. aureus mastitis; however, because of limited adoption and application of these control measures $S$. aureus mastitis continues to be the most common disease that causes major economic losses in dairy cattle production.

Therefore, a sustainable intervention tool such as an effective vaccine is required to control staphylococcal mastitis during these critical periods to improve productivity and wellbeing of dairy cows. One of the major constraints affecting the development of an effective vaccine against $S$. aureus mastitis is the absence of uniform and good experimental challenge model that mimics natural intramammary infection (IMI). Intramammary infusion of S. aureus is a reliable method in terms of inducing experimental S. aureus mastitis [14-16]; however, it is an unrealistic infection model since it bypasses physical barriers at teat opening, non-specific natural defenses and inducible innate and acquired immune effectors in the teat canal. Moreover, intramammary infusion overwhelms the host immunological defenses because the number of bacteria infused into the intramammary area during experimental challenge $[17,18]$ is much higher than natural infection. Therefore, a challenge model that is closely similar to natural infection is required for evaluation of the efficacy of an experimental vaccine against $S$. aureus mastitis. The objective of this study was to develop an experimental $S$. aureus mastitis challenge model by teat dipping in a S. aureus culture suspension.

\section{Materials and Methods}

\subsection{Study Animals}

This study was approved by the University of Tennessee's Animal Care and Use Committee (IACUC\#=2394-1115). Prior to the enrolment in the study, all cows were tested for the presence of IMI by culturing milk samples and analysis of somatic cell count (SCC). A total of 8 pregnant Holstein dairy cows within 1st to 3rd lactation in the early dry period were divided into two groups of experimental $(n=5)$ and control $(n=3)$ cows (Table 1). All cows were free of IMI and had average composite milk SCC of $\leq 250,000 / \mathrm{mL}$ of milk except one cow, which had an average SCC of 399,750/mL of milk with no bacterial growth from milk. Experimental and control cows were under the same herd management throughout the study and housed at the East Tennessee Research and Education Center-Little River Animal and Environmental Unit (ETREC-LAEU), Walland, Tennessee. 
Table 1. Experimental challenge (infection) protocol of S. aureus.

\begin{tabular}{ccccc}
\hline Group & No. of Cows & Challenge Strain & Challenge Dose $(\mathrm{CFU} / \mathbf{m L})$ & Challenge Route \\
\hline 1 & 5 & SAUT2 & $1 \times 10^{5}$ & Teat Dip ** \\
2 & 3 & None & PBS (Control) & Teat Dip ** \\
\hline
\end{tabular}

*: Staphylococcus aureus strain 2 from the University Tennessee collection; isolated originally from milk of a cow with intramammary infection. ${ }^{* *}$ : Teat dipping into bacterial culture suspension for $15 \mathrm{~s}$.

\subsection{Bacterial Growth Condition}

Staphylococcus aureus strain UT2 (SAUT2) used as the challenge strain was originally isolated from a dairy cow with mastitis. An aliquot from a frozen vial of S. aureus strain UT2 stored at $-80{ }^{\circ} \mathrm{C}$ in glycerol/Tryptic soy broth (TSB) was inoculated onto Tryptic soy agar (TSA) plates with $5 \%$ sheep blood (Becton Dickinson Microbiology System, Cockeysville, MD, USA) and grown overnight ( $24 \mathrm{~h}$ ) at $37^{\circ} \mathrm{C}$. After incubation, 3 colonies were inoculated into $1 \mathrm{~L}$ of TSB and grown to mid-log phase $\left(\mathrm{OD}_{600}\right.$ : 0.4-0.5) achieved the challenge culture concentration of $1 \times 10^{5} \mathrm{CFU} / \mathrm{mL}$ approximately after $3.5 \mathrm{~h}$ of growth at $37^{\circ} \mathrm{C}$.

\subsection{Experimental Challenge (Infection)}

Experimental challenge (infection) started 10 days after drying off and was conducted once daily for 14 days. Prior to challenge, teats were washed thoroughly with water and a mild dish detergent without antibacterial effects and dried with individual paper towel. Culture suspension was aliquoted into $100 \mathrm{~mL}$ individual cups per cow and all available teats were challenged by immersing teats in the culture suspension for $15 \mathrm{~s}$. Challenged teats were allowed to air dry for $10 \mathrm{~min}$ prior to releasing cows from the parlor. Immediately before and after the challenge, bacterial suspension was cultured to determinate $S$. aureus number using a viable plate count. To ensure parlor disinfection after challenge, floor was disinfected by bleach at 1:10 dilution. On the $\mathrm{Ch}+15$ each quarter of experimental cows were treated by infusion of $10 \mathrm{~mL}$ suspension containing $500 \mathrm{mg}$ ceftiofur hydrochloride for dry cows (Spectramast ${ }^{\circledR}$ DC, Zoetis Inc. Kalamazoo, MI, USA).

\subsubsection{Clinical Examination of Challenged Cows}

During challenge period, severity of local inflammatory changes on mammary secretion and mammary glands (Table 2 and Appendix B), rectal body temperature (Appendix A), somatic cell count (SCC) and bacterial count were monitored and recorded daily. Animals were observed daily for loss of appetite, restlessness, loss of mobility, and unresponsiveness throughout the study time. The macroscopic inflammatory changes in the mammary secretion was scored as $0=$ normal, $1=$ flakes, 2 = clots, 3 = stringy/watery/bloody (Table 2 ). Inflammatory changes in the mammary gland tissue were scored as $0=$ normal; the udder is pliable, no detection of heat, pain, redness, and/or swelling, 1 = slight swelling; the udder is less pliable, some firmness detected, heat, pain, redness, and/or swelling not necessarily detected, 2 = moderate swelling; the udder is firm, redness and heat detected, discomfort detected, 3 = severe swelling; the udder is very hard, red and hot, noticeable difference compared to other quarters and the cow exhibit signs of irritation (Table 2). In this study, clinical mastitis was defined as a score of 2 for both milk and udder tissue or a score of 3 either in milk or in udder tissue for three consecutive days. A week prior to drying off during the prescreening, subclinical mastitis was defined as somatic cell count (SCC) of $>200,000 / \mathrm{mL}$ of composite milk from all quarters or $>100,000 / \mathrm{mL}$ of milk from the individual quarters with positive isolation of the mastitis-causing bacteria from milk for three consecutive days without clinical signs of mastitis. Somatic cell count (SCC) of dry cow secretion rises markedly and may reach up to $2 \times 10^{7}$ cells $/ \mathrm{mL}$ of dry secretion after first week of dry period due to the recruitment of cells into the involuting gland and the increase in cell number due to reduction in fluid volume of mammary secretion $[19,20]$. Because of that, after drying off, somatic cell count was not used as one of the criteria to determine infection but the continuous 
high count of the challenge strain of bacteria from mammary secretion for 3 consecutive days without clinical signs of mastitis was considered a subclinical infection.

Table 2. Inflammatory changes in dry secretion and mammary gland tissue scoring scheme.

\begin{tabular}{cll}
\hline Dry Secretion Appearance & Score & \multicolumn{1}{c}{ Mammary Gland Appearance } \\
\hline Normal & 0 & $\begin{array}{l}\text { Normal; the udder is pliable. Heat, pain, redness, and/or } \\
\text { swelling are not detectable. Cow exhibits no signs } \\
\text { of discomfort. }\end{array}$ \\
\hline Flakes & 1 & $\begin{array}{l}\text { Slight swelling; the udder is less pliable with some firmness } \\
\text { or heavier in weight. Redness, heat, and pain are generally } \\
\text { not detectable. }\end{array}$ \\
\hline Slugs/clots & $\begin{array}{l}\text { Moderate swelling; the udder is firm, heavy, reddened and } \\
\text { warm to the touch. The cow generally exhibits signs of } \\
\text { discomfort (irritable, performs a stepping motion with feet } \\
\text { and/or kicks) during evaluation. }\end{array}$ \\
\hline Stringy/watery/bloody & 3 & $\begin{array}{l}\text { Severe swelling; the udder is very hard, heavy, red and hot, } \\
\text { and noticeably larger than other quarters. The cow is } \\
\text { extremely uncomfortable, very irritable and manifests pain by } \\
\text { kicking and stepping. }\end{array}$ \\
\hline
\end{tabular}

\subsubsection{Sample Collection}

\section{Milk or Mammary Secretion and Blood Sample Collection}

The small volume of milk (2-10 mL) was collected 7 days before drying off (D-7), at drying off (D0), and mammary secretion during challenge period at days 0 to $7(\mathrm{Ch} 0-\mathrm{Ch}+7)$, day $10(\mathrm{Ch}+10)$ and, day $14(\mathrm{Ch}+14)$ of challenge. Individual quarter milk samples were collected on the day of calving $(\mathrm{C})$ and 3 days after calving $(C+3)$ to assess presence of challenge strain of $S$. aureus (Table 3). Samples were collected aseptically in sterile $15 \mathrm{~mL}$ tubes, placed on ice and transported to the laboratory. Blood samples were collected 7 days before drying off (D-7), at drying off (D0), immediately before challenge (Ch0) and at days 3, 7 and 14 of challenge $(\mathrm{Ch}+3, \mathrm{Ch}+7$, and $\mathrm{Ch}+14)$ to determine immunological responses of cows to $S$. aureus infection (Table 3). Immediately after collection, samples were centrifuged at $2500 \mathrm{rpm}$ for $20 \mathrm{~min}$ at $4^{\circ} \mathrm{C}$ and serum was separated and stored at $-20{ }^{\circ} \mathrm{C}$ until evaluated by ELISA assay.

Table 3. Sample collection and data recording schedule.

\begin{tabular}{lc}
\hline \multicolumn{1}{c}{ Sample Type } & Sample Collection Time (Day) \\
\hline Milk samples for bacteriological culture and somatic cell count & $\mathrm{D}-7, \mathrm{D} 0, \mathrm{C}, \mathrm{C}+3$ \\
\hline $\begin{array}{l}\text { Mammary secretion for bacteriological culture and somatic cell } \\
\text { count and flow cytometry }\end{array}$ & $\mathrm{Ch} 0-\mathrm{Ch}+7, \mathrm{Ch}+10, \mathrm{Ch}+14$, \\
\hline $\begin{array}{l}\text { Blood samples to measure systemic antibody titers against } \\
\text { challenge strain }\end{array}$ & $\mathrm{Ch}$, Ch+7 and Ch+14 \\
\hline Rectal body temperature & $\mathrm{D}-7, \mathrm{D} 0, \mathrm{Ch} 0-\mathrm{Ch}+14$ \\
\hline $\begin{array}{l}\text { Recoding scores of inflammatory changes in the mammary } \\
\text { secretion and mammary gland tissue }\end{array}$ & $\mathrm{Ch} 0-\mathrm{Ch}+7, \mathrm{Ch}+10$ and Ch+14 \\
\hline $\begin{array}{l}\text { D-: Day before drying off, D+: Day after drying off, D0: Day of drying off, Ch0: immediately before challenge, } \\
\text { Ch+: Day of challenge, C: Calving day, C+: Day after calving. }\end{array}$
\end{tabular}


Milk or Mammary Secretion Somatic Cell Count (SCC) and Bacterial Count

Somatic cell count and bacterial count of milk or mammary secretion samples were determined at the Dairy Herd Improvement Association Laboratory and Tennessee Quality Milk Laboratory (Knoxville, TN, USA), respectively.

Bacteriological culturing was conducted following the National Mastitis Council guidelines as described by Oliver et al. [21]. Briefly, $100 \mu \mathrm{L}$ of milk was streaked onto Tryptic soy agar with 5\% sheep blood (blood agar plates) (Becton Dickinson Microbiology system, Cockeysville, MD, USA) and incubated at $37^{\circ} \mathrm{C}$ for $24-48 \mathrm{~h}$ until colony growth was observed. Colony characteristics such as morphology, color, and hemolysis pattern on blood agar plates were recorded. Each colony was Gram-stained and Gram-positive cocci were further tested by catalase test to differentiate staphylococci from streptococci. The catalase-positive Staphylococcus isolates were further tested by tube coagulase test using rabbit plasma to differentiate S. aureus from coagulase-negative Staphylococcus spp. (CNS). Those that were catalase-positive and coagulase-positive were identified as Staphylococcus aureus.

\subsubsection{Pulsed-Field Gel Electrophoresis (PFGE)}

Molecular fingerprinting of challenge strain of S. aureus that presents in the mammary secretion during the challenge period was assessed using PFGE as described elsewhere [22,23]. Briefly, each bacterial isolate from mammary secretion during the challenge period that was identified as Staphylococcus aureus was stocked at $-80^{\circ} \mathrm{C}$ in Glycerol/TSB. Each isolate was inoculated on a blood agar plate and incubated overnight. A single pure colony was inoculated to $5 \mathrm{~mL}$ of Brain Heart Infusion (BHI) broth (Becton Dickinson Microbiology system, Cockeysville, MD) and incubated at $37^{\circ} \mathrm{C}$ for $24 \mathrm{~h}$ with shaking at $220 \mathrm{rpm}$. Bacterial concentration was adjusted to an $\mathrm{OD}_{600}$ of 0.9 to 1.1 with phosphate-buffered saline (PBS $=\mathrm{pH}$ 7.2) using a spectrophotometer (Bio-Rad Laboratories, Hercules, CA). A $200 \mu \mathrm{L}$ aliquot of the culture was pelleted and re-suspended in $300 \mu \mathrm{L}$ of Tris-EDTA buffer ( $\mathrm{pH}$ 8.0). The suspension was mixed with $1.8 \%(\mathrm{w} / \mathrm{v})$ InCert agarose (Lonza, Rockland, ME, USA) in Tris-EDTA buffer (ThermoFisher Scientific, Waltham, MA), dispensed into the wells of disposable plug mold (Bio-Rad) and digested with lysostaphin $(1 \mathrm{mg} / \mathrm{mL}$ in $20 \mathrm{mM}$ sodium acetate, $\mathrm{pH}$ 4.5; Sigma Aldrich, St. Louis, Missouri). Plugs were washed four times in $4 \mathrm{~mL}$ of Tris-EDTA buffer at $37^{\circ} \mathrm{C}$ for $20 \mathrm{~min}$. Following the wash step, agar plugs were cut into a $2 \times 2 \mathrm{~mm}$ size, equilibrated in $1 \times \mathrm{SmaI}$ restriction buffer for $30 \mathrm{~min}$ and digested with $S m a \mathrm{I}(10 \mathrm{U} / \mu \mathrm{L}$, New England BioLabs Inc., Ipswich, MA, USA $)$ in a total volume of $200 \mu \mathrm{L}(3 \mu \mathrm{L} \mathrm{SmaI}+197 \mu \mathrm{L}$ of $1 \times$ buffer $)$ at $25^{\circ} \mathrm{C}$ for $3 \mathrm{~h}$. A single plug was loaded on to each tooth of 15 combs with the control S. aureus strain NCTC 8325 and incubated at room temperature for $20 \mathrm{~min}$. The comb was placed in the gel-casting platform and $1 \%$ SeaKem agarose was added and kept at room temperature for $20 \mathrm{~min}$ until solidified. Gel electrophoresis was conducted using the CHEF Mapper (Bio-Rad) at the initial switch of $5 \mathrm{~s}$, with a final switch of $40 \mathrm{~s}$ and running time for $21 \mathrm{~h}$ at $200 \mathrm{~V}(6 \mathrm{~V} / \mathrm{cm})$ at the temperature of $14^{\circ} \mathrm{C}$ using ramp angle of $120^{\circ}$. The gel was stained with ethidium bromide ( $1.25 \mu \mathrm{g}$ per $\mathrm{mL}$ of water, (Invitrogen, Carlsbad, CA) for $25 \mathrm{~min}$ and washed twice for $30 \mathrm{~min}$ with fresh distilled water. The images were taken using ChemiDoc ${ }^{\circledR}$ Touch Imaging System (Bio-Rad Laboratories, Hercules, CA, USA), exported to GelCompar II software (Applied Maths Inc., Austin, TX, USA)(Bio-Rad Laboratories, Hercules, CA, USA) and saved as a TIFF file. The TIFF images of PFGE were imported and analyzed using GelCompar II software (Applied Maths Inc., Austin, TX, USA). The intra- and inter-gel PFGE runs were normalized using control $S$. aureus strain NCTC8325. The bands ranging from 10 to $674 \mathrm{~kb}$ were used for analysis.

\subsubsection{Evaluation of Systemic Humoral Immune Responses Against S. Aureus Infection by ELISA}

Serum anti-Staphylococcus aureus IgG titer was determined using an indirect enzyme-linked immunosorbent assay (ELISA) as described by [24]. Briefly, 96 well polystyrene plates (Immulon ${ }^{\circledR} 2 \mathrm{HB}$ ) (ThermoScientific, Rochester, NY, USA) were coated with $1 \mu \mathrm{g} / \mathrm{mL}$ of $S$. aureus surface proteins (SASP) in a sodium bicarbonate $\left(\mathrm{NaHCO}_{3}\right)$ coating buffer [0.015 molar (M) Sodium Carbonate $\left(\mathrm{Na}_{2} \mathrm{CO}_{3}\right)$ 
and $0.034 \mathrm{M}$ Sodium Bicarbonate $\left(\mathrm{NaHCO}_{3}\right)$ solution of $\mathrm{pH}$ 9.6] and incubated overnight at $4{ }^{\circ} \mathrm{C}$. The coating buffer was removed, and plates were washed $5 \times$ using an automated 405 touch screen (TS) microplate washer (Biotek instrument Inc, Winooski, VT, USA) with PBS containing $0.05 \%$ tween $20^{\circledR}$ (v/v) (PBS-T, Bio-Rad Laboratories, Hercules, CA, USA) and blocked with PBS-T containing 1\% gelatin $(\mathrm{W} / \mathrm{V})(\mathrm{PBS}-\mathrm{TG})$ for $2 \mathrm{~h}$. The plates were washed $5 \times$ with PBS-T and serum was serially diluted four-fold with PBS-TG starting from 1:100 dilution and incubated for $1 \mathrm{~h}$ at room temperature. Plates were washed $5 \times$ and $100 \mu \mathrm{L}$ of 1:10,000 diluted (in PBS-TG) horseradish peroxidase-conjugated polyclonal sheep anti-bovine IgG (heavy + Light Chain) (Bethyl Laboratories, Inc. Montgomery, TX, USA) were added and incubated for $1 \mathrm{~h}$ at room temperature. After incubation, plates were washed $5 \times$ with PBS-T, and $100 \mu \mathrm{L}$ of $\mathrm{ABTS}^{\mathrm{TM}}$ horseradish peroxidase substrate (SeraCare Life Sciences, Milford, MA, USA) were added and incubated for $20 \mathrm{~min}$ at room temperature. The absorbance was read at a wavelength of $405 \mathrm{~nm}$ using a Synergy H1 Microplate reader (Biotek instrument Inc, Winooski, VT, USA). Data were exported to Excel (Microsoft Corporation. Redmond, WA, USA) and the average +2 standard deviations (avg +2 stdev) of the blank row, which received everything except primary antibody (serum), were used to determine the cutoff point for titer calculation. Serum titers were calculated by the intersection of the least-square regression of $\mathrm{A}_{405}$ versus the logarithm of dilution.

\subsection{Statistical Analysis}

To assess the effect of experimental S. aureus mastitis challenge (infection) by teat dipping in bacterial culture suspension on development of mastitis, systemic humoral responses a mixed model ANOVA was used (SAS 9.4, SAS Institute Inc., Cary, NC, USA). Continuous measures were assessed using a mixed model ANOVA evaluating the fixed effects of teat dip challenge (treatment) or control at certain time points during the challenge (e.g., $\mathrm{Ch} 0-\mathrm{Ch}+7, \mathrm{Ch}+10$, and $\mathrm{Ch}+14$ ), the interaction of the treatment and day, cow (challenged, control). A significant effect was declared when $p \leq 0.05$.

\section{Results}

\subsection{Clinical Examination of Results during Challenge Study}

Cow level infection reached $80 \%(4 / 5)$ by day 3 of challenge, whereas quarter level infection reached a maximum of $81.3 \%$ (13/16) by day 6 of challenge (Figure 1, Figure 2 and Appendix B). Only one cow out of the four S. aureus-infected cows developed clinical mastitis in the left rear (LR) quarter by day 10. The remaining cow from experimental group was infected by Staphylococcus choromogenes and exclude from further data analysis. Rectal body temperature was monitored daily throughout the 14 days of the challenge period. No significant differences of mean rectal body temperatures $\left({ }^{\circ} \mathrm{C}\right)$ between the experimental $\left(38.53^{\circ} \mathrm{C}\right)$, and the control $\left(38.59^{\circ} \mathrm{C}\right)$ groups were observed (Appendix A).

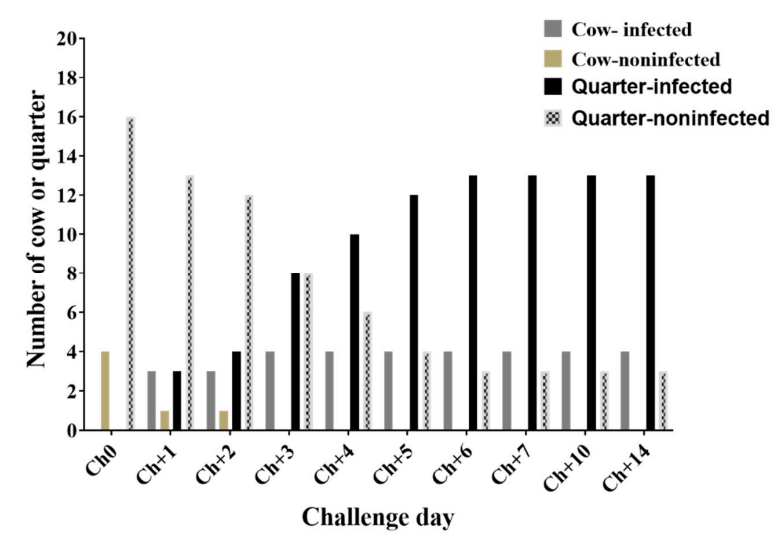

Figure 1. Intramammary infection status of cows or quarters with $S$. aureus during challenge period. Ch0: immediately before the challenge, days 1 to 7 of challenge $(\mathrm{Ch}+1-\mathrm{Ch}+7)$, days 10 and 14 of challenge $(\mathrm{Ch}+10$ and $\mathrm{Ch}+14)$. 


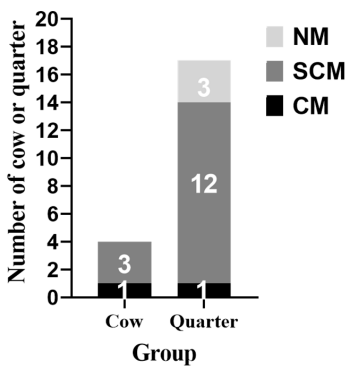

Figure 2. Cow and quarter level infection status. CM: Clinical mastitis, SCM: Subclinical mastitis, NM: No mastitis.

\subsection{Number of S. Aureus Count (CFU/Ml) in the Mammary Secretion}

The mean number of $S$. aureus count in mammary secretion ranged from $1.3 \times 10^{4} \mathrm{CFU} / \mathrm{mL}$ to $1.4 \times 10^{5} \mathrm{CFU} / \mathrm{mL}$ at day 1 and 10 of challenge, respectively (Figure 3 ). All infected quarters shed SAUT2 strain as confirmed by pulsed-field gel electrophoresis results (Figure 4). Bacteriological culture results of milk samples collected at calving (C) and three days after parturition (C+3) was negative for challenge strain of $S$. aureus indicating that post experimental treatment at $\mathrm{Ch}+15$ with antibiotic cleared the infection.

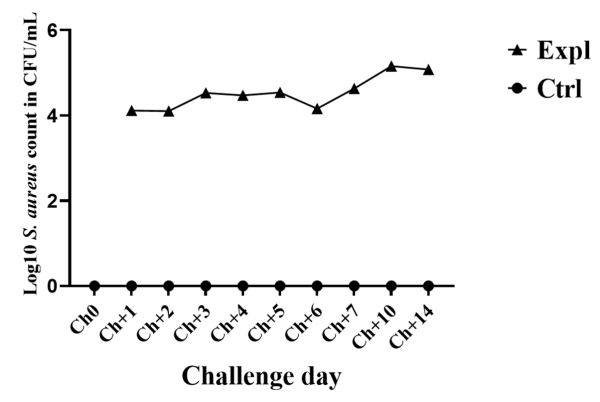

Figure 3. Staphylococcus aureus counts $(\mathrm{CFU} / \mathrm{mL})$ from mammary secretion during challenge period.

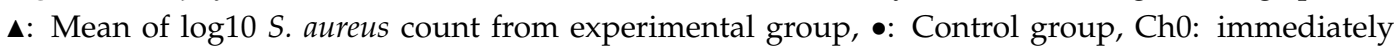
before challenge. $\mathrm{Ch}+1-\mathrm{Ch}+7$ : days 1 to 7 of challenge. $\mathrm{Ch}+10$ and $\mathrm{Ch}+14$ : days 10 and 14 of challenge, respectively.

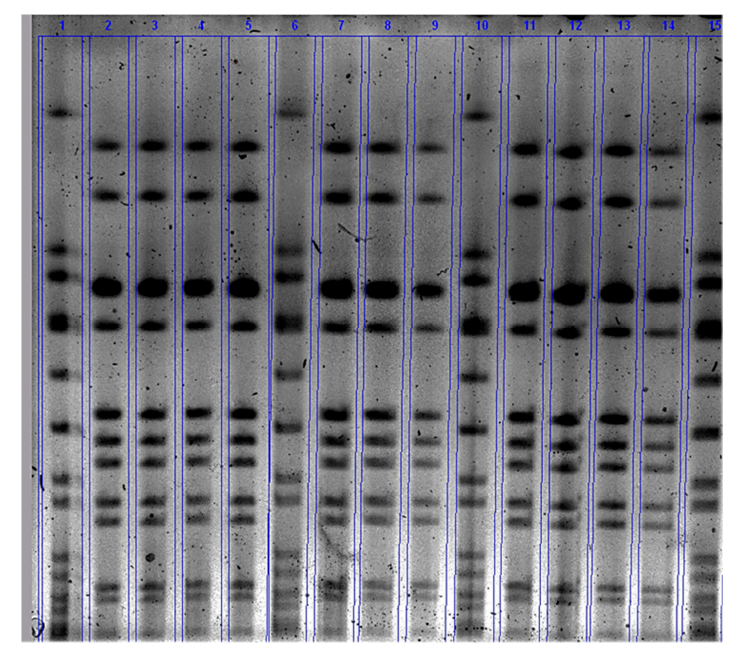

Figure 4. Banding patterns obtained from SmaI digested DNA and pulsed field gel electrophoresis (PFGE) of S. aureus strains isolated from mammary secretion from left rear of 4398 cow during challenge period. Lanes 1, 6,10 and 15: S. aureus strain NCTC8325 (internal control strain for PFGE analysis); Lanes 2 and 14: S. aureus challenge strain UT2; Lines 3, 4, 5, 7, 8, 9, 11, 12 and 13: S. aureus isolates identified on day $1,2,3,4,5,6,7,10$ and 14 , respectively. 


\subsection{Systemic Immunological Responses of Dairy Cows against S. Aureus Intramammary Infection}

There were high background anti-S. aureus IgG titers in both control and experimental cows prior to experimental infection. Infection by $S$. aureus induced a slight increase in serum anti-S. aureus IgG titers at days 7 and 14 of the challenge but not significantly different from non-infected control cows (Figure 5).

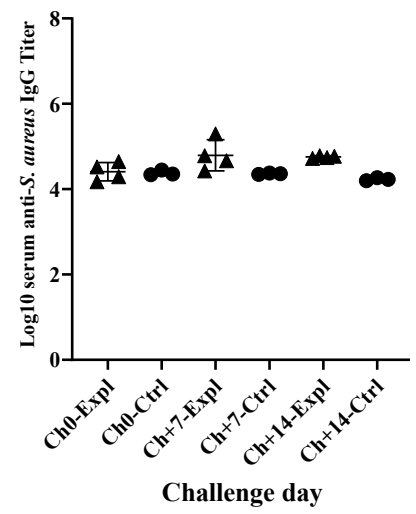

Figure 5. Serum anti-S. aureus IgG titers of experimental (Expl: $\mathbf{\Delta})$ and control (Ctrl: •) cows at days 0, 7 and 14 of challenge. No significant difference between experimental and control groups.

\section{Discussion}

Experimental S. aureus intramammary infection was induced by teat dipping into freshly growing bacterial culture suspension at mid-log phase of growth daily. Three cows were infected by day three of challenge in at least one quarter and most quarters by day four of challenge. Despite differences in challenge methods and physiological status of study animals these results are similar to that of Enger et al. [17] who reported that intramammary infusion of S. aureus resulted in established intramammary infection (IMI) in 18 of the 19 infused quarters with increased somatic cell count. However, this study challenged pregnant cows at early dry period (14-28 days after drying off) by dipping all available teats in S. aureus culture suspension of approximately $1 \times 10^{7} \mathrm{CFU} / \mathrm{mL}$ of growth media. In their study [17] mammary glands of non-pregnant dry cows after 45 days of drying of were induced to grow by subcutaneous injections of estradiol and progesterone daily for 7 days followed by intramammary infusion of one quarter of each cow with $S$. aureus suspension of $7.5 \times 10^{3} \mathrm{CFU} / \mathrm{mL}$. Enger et al. [17] also reported greater number of somatic cell count dominated by neutrophils in $S$. aureus challenged quarters compared with saline infused control quarters.

In this study, at drying off (D0) all cows had somatic cell count (SCC) of less than 250,000 cells/mL of milk except one cow which had average SCC of 399,750 cells/mL of milk with no bacterial growth from milk; however, 14 days after dying off immediately before challenge (Ch0) all cows had high somatic cell count in the range of millions $\left(1 \times 10^{6}\right.$ cells/ $\mathrm{mL}$ of dry secretion or greater $)$. There were high counts in the dry secretion of all cows because of recruitment of leukocytes into involuting gland and reduction in the volume of mammary secretion, so somatic cell count was not used to assess infection status. Study by Schukken et al. [16] reported that intramammary infusion of 300-600 CFU/mL of S. aureus in the late lactation resulted in 79\% (107/135) and 20.7\% (28/135) of cows with established and no stablished infection, respectively. Our results indicated that four of five cows (80\%) developed established IMI and one cow developed S. chromogenes IMI and excluded from data analysis. In another study [25] intramammary infusion of 2.41 to $2.93 \log 10$ CFU of S. aureus into two quarters per cow of 68 first lactation Holstein dairy cows resulted in infection of 135 (99\%) of 136 challenged quarters. These authors [25] also reported that of 136 quarters challenged, S. aureus was not detected in milk from one quarter throughout the entire experimental period of three weeks. In our study, established IMI was developed only in 13 of 16 quarters challenged. Similarly, Bannerman et al. [26] found that intramammary infusion of 10 Holstein dairy cows at mid-lactation with $67 \mathrm{CFU}$ of S. aureus into one quarter of each cow resulted in infection of all challenged quarters within $16 \mathrm{~h}$ of challenge. These 
authors [26] reported that somatic cell counts were increased by $24 \mathrm{~h}$ post-challenge and remained high throughout the study with eight of ten cows became infected until end of the study on day 8 of challenge. In our study the cow level infection was $80 \%$ which is similar to the $80 \%$ reported by Bannerman et al. [26]. Using a mildly-virulent strain of S. aureus, Eckersall et al. [27] developed experimental subclinical $S$. aureus mastitis by intramammary infusion of $5 \times 10^{4}$ CFU in $10 \mathrm{~mL}$ of Ringers buffered salt solution. These authors [27] reported that infusion of two-quarters of each cow at two-time points, at drying off and 28 days after drying off (D0 and D+28) induced subclinical mastitis in eight of 10 infused cows and two cows did not develop mastitis. Petzl et al. [28] induced experimental subclinical S. aureus infection in 1st lactation dairy cows at 3 to 5 months post-partum (mid-lactation) by intracisternal inoculation of $10^{4} \mathrm{CFU}$ in $2 \mathrm{~mL}$ of $0.9 \%$ sterile pyrogen-free saline within $72 \mathrm{~h}$ of the challenge.

Most of the challenge infections were induced by intramammary infusion of large number of S. aureus. However, in this study, we induced closely similar results by dipping teats in S. aureus culture suspension.

The intramammary infusion of $S$. aureus is a well-established method to induce experimental $S$. aureus mastitis in dairy cows $[14-17,25,26,28]$. The intramammary infusion of $S$. aureus is a reliable method in terms of causing infection but it is an unrealistic method in terms of mimicking naturally occurring intramammary infections because large number of bacteria are directly delivered into the intramammary area bypassing physical barriers and non-specific natural defenses, as well as inducible innate and acquired immune responses at teat opening and in the teat canal. The intramammary infusion could be a good model to study the pathogenesis of mastitis but not for evaluation of vaccine efficacy against mastitis. Therefore, an experimental challenge model that is closely similar to natural infection is necessary for the evaluation of vaccine efficacy against S. aureus mastitis in dairy cows. This teat dipping based infection model is closely similar to natural infection and it is good infection model for evaluation of vaccine efficacy.

\section{Conclusions}

In conclusion, experimental $S$. aureus mastitis can be induced by teat dipping in the bacterial culture suspension without infusing bacteria into the intramammary area. This infection model is good for testing vaccine efficacy because it is closely similar to natural infection.

Author Contributions: Conceptualization of the study and experimental design O.K.D.; milk samples collection, Flow cytometry analysis, review and editing the article, G.M.P.; milk or mammary secretion samples collection, bacteriological culturing, somatic cell count, review and editing the article, B.E.G.; Experimental infection, blood samples collection, antibody analysis, overall data analysis and writing the article, O.K.D. and P.A.P. All authors have read and agreed to the current version of the manuscript.

Funding: This research received no external funding.

Acknowledgments: We would like to express our sincere appreciation for all staff of East Tennessee Research and Education Center-Little River Animal and Environmental Unit for their help during the experiment.

Conflicts of Interest: The authors declare no conflict of interest.

\section{Appendix A}

Table A1. Rectal body temperature during the challenge period. G: Group, cow ID: cow identification number (only last two digits were shown for the confidentiality of farm and cow identity), Expl: Experimental Group, Ctrl: Control Group. Ch0: Immediately before challenge. $\mathrm{Ch}+1-\mathrm{Ch}+10$ : days 1 to 10 of challenge; $\mathrm{Ch}+14$ : day 14 of challenge.

\begin{tabular}{|c|c|c|c|c|c|c|c|c|c|c|c|c|c|}
\hline Group & Cow ID & $\mathrm{Ch}+0$ & $\mathrm{Ch}+1$ & $\mathrm{Ch}+2$ & $\mathrm{Ch}+3$ & $\mathrm{Ch}+4$ & $\mathrm{Ch}+5$ & $\mathrm{Ch}+6$ & $\mathrm{Ch}+7$ & $\mathrm{Ch}+88$ & $\mathrm{Ch}+9$ & $\mathrm{Ch}+10$ & $\mathrm{Ch}+14$ \\
\hline \multirow{4}{*}{ Expl } & -24 & 38.7 & 38.6 & 38.5 & 38.3 & 38.5 & 38.4 & 38.3 & 38.4 & 38.6 & 38.5 & 38.2 & 38.1 \\
\hline & -28 & 38.4 & 38.4 & 38.6 & 38.4 & 38.4 & 38.3 & 38.6 & 38.5 & 38.5 & 37.7 & 38.3 & 38.4 \\
\hline & -98 & 38.5 & 38.2 & 38.1 & 38.4 & 38.5 & 38.3 & 38.8 & 38.4 & 38.8 & 39 & 39 & 39.3 \\
\hline & -94 & 38.5 & 38.2 & 38.6 & 38.6 & 38.6 & 38.6 & 38.3 & 38.4 & 38.7 & 38.4 & 38.3 & 38.6 \\
\hline
\end{tabular}


Table A1. Cont.

\begin{tabular}{|c|c|c|c|c|c|c|c|c|c|c|c|c|c|}
\hline Group & Cow ID & $\mathrm{Ch}+0$ & $\mathrm{Ch}+1$ & $\mathrm{Ch}+2$ & $\mathrm{Ch}+3$ & $\mathrm{Ch}+4$ & $\mathrm{Ch}+5$ & $\mathrm{Ch}+6$ & $\mathrm{Ch}+7$ & $\mathrm{Ch}+88$ & $\mathrm{Ch}+9$ & $\mathrm{Ch}+10$ & $\mathrm{Ch}+14$ \\
\hline \multirow{3}{*}{ Ctrl } & -58 & 38.6 & 38.5 & 38.8 & 38.7 & 38.6 & 38.6 & 38.5 & 38.7 & 38.6 & 38.7 & 38.5 & 38.6 \\
\hline & -71 & 38.6 & 38.3 & 38.6 & 38.4 & 38.4 & 38.5 & 38.1 & 38.4 & 38.3 & 38.5 & 38.5 & 38.7 \\
\hline & -73 & 38.7 & 38.7 & 38.7 & 38.6 & 38.6 & 38.7 & 38.5 & 38.7 & 38.6 & 38.7 & 38.4 & 38.3 \\
\hline
\end{tabular}

\section{Appendix B}

Table A2. Score results of inflammatory changes in the mammary glands during challenge period. 0: normal, 1: flakes, 2: clots, 3: stringy/watery/bloody. G: Group, Expl: Experimental Group, CID: Cow Identification number (only last two digits were shown for confidentiality of farm and cow identity), Ctrl: Control Group, Qr: quarter, Ch0: Immediately before challenge, $\mathrm{Ch}+1-\mathrm{Ch}+10$ : days 1-10 of challenge and day 14 of challenge $(\mathrm{Ch}+14)$, RF: right front quarter, RR: right rear quarter, LR: left rear quarter, LF: Left front quarter.

\begin{tabular}{|c|c|c|c|c|c|c|c|c|c|c|c|c|c|c|}
\hline G & CID & Qr. & $\mathrm{Ch}+0$ & $\mathrm{Ch}+1$ & $\mathrm{Ch}+2$ & $\mathrm{Ch}+3$ & $\mathrm{Ch}+4$ & $\mathrm{Ch}+5$ & $\mathrm{Ch}+6$ & $\mathrm{Ch}+7$ & $\mathrm{Ch}+8$ & $\mathrm{Ch}+9$ & $\mathrm{Ch}+10$ & $\mathrm{Ch}+14$ \\
\hline \multirow{11}{*}{ Expl } & \multirow{3}{*}{-24} & $\mathrm{RF}$ & 1 & 0 & 0 & 1 & 0 & 0 & 1 & 0 & 1 & 0 & 1 & 1 \\
\hline & & RR & 0 & 0 & 0 & 1 & 1 & 1 & 1 & 1 & 1 & 1 & 1 & 1 \\
\hline & & $\mathrm{LF}$ & 0 & 0 & 0 & 0 & 0 & 0 & 0 & 0 & 0 & 0 & 0 & 0 \\
\hline & \multirow{3}{*}{-28} & RF & 0 & 0 & 0 & 0 & 0 & 1 & 0 & 0 & 0 & 0 & 0 & 0 \\
\hline & & RR & 1 & 1 & 0 & 1 & 1 & 1 & 1 & 1 & 0 & 1 & 1 & 1 \\
\hline & & $\mathrm{LF}$ & 1 & 1 & 0 & 0 & 0 & 0 & 0 & 1 & 1 & 0 & 0 & 1 \\
\hline & \multirow{4}{*}{-98} & $\mathrm{RF}$ & 0 & 0 & 0 & 0 & 1 & 0 & 0 & 0 & 1 & 1 & 1 & 0 \\
\hline & & RR & 0 & 0 & 0 & 0 & 0 & 1 & 0 & 0 & 1 & 1 & 0 & 0 \\
\hline & & LR & 0 & 1 & 0 & 0 & 1 & 1 & 1 & 1 & 2 & 2 & 2 & \\
\hline & & $\mathrm{LF}$ & 0 & 0 & 0 & 0 & 0 & 0 & 0 & 0 & 1 & 0 & 1 & 1 \\
\hline & -94 & $\mathrm{LF}$ & 0 & 0 & 0 & 0 & 0 & 0 & 0 & 1 & 0 & 0 & 0 & 0 \\
\hline \multirow{9}{*}{ Ctrl } & \multirow{4}{*}{-58} & $\mathrm{RF}$ & 0 & 0 & 0 & 0 & 0 & 0 & 0 & 0 & 0 & 0 & 0 & 1 \\
\hline & & RR & 0 & 0 & 0 & 0 & 0 & 0 & 0 & 0 & 0 & 0 & 0 & 0 \\
\hline & & LR & 0 & 0 & 0 & 0 & 0 & 0 & 0 & 0 & 0 & 0 & 0 & 0 \\
\hline & & $\mathrm{LF}$ & 0 & 0 & 0 & 0 & 1 & 0 & 0 & 0 & 0 & 0 & 1 & 0 \\
\hline & \multirow{4}{*}{-71} & $\mathrm{RF}$ & 0 & 1 & 0 & 0 & 1 & 0 & 0 & 0 & 0 & 0 & 1 & 0 \\
\hline & & RR & 0 & 0 & 0 & 0 & 0 & 1 & 1 & 0 & 0 & 0 & 1 & 0 \\
\hline & & LR & 0 & 0 & 0 & 0 & 0 & 0 & 0 & 0 & 0 & 0 & 0 & 0 \\
\hline & & $\mathrm{LF}$ & 0 & 0 & 0 & 0 & 0 & 0 & 0 & 1 & 0 & 0 & 0 & 0 \\
\hline & -73 & $\mathrm{RF}$ & 0 & 0 & 0 & 1 & 0 & 1 & 0 & 1 & 0 & 0 & 0 & 0 \\
\hline
\end{tabular}

\section{References}

1. DeGraves, F.J.; Fetrow, J. Economics of mastitis and mastitis control. Vet. Clin. N. Am. Food Anim. Pract. 1993, 9, 421-434. [CrossRef]

2. Ismail, Z.B. Mastitis vaccines in dairy cows: Recent developments and recommendations of application. Vet. World 2017, 10, 1057. [CrossRef] [PubMed]

3. USDA APHIS. Antibiotic use on U.S. dairy operations, 2002 and 2007 (infosheet, 5p, October, 2008). 2008. Available online: https://www.aphis.usda.gov/animal_health/nahms/dairy/downloads/dairy07/Dairy07_is_ AntibioticUse_1.pdf (accessed on 23 March 2020). 
4. USDA APHIS. United States Department of Agriculture, Animal Plant Health Inspection Service National Animal Health Monitoring System. Highlights of Dairy 2007 Part III: Reference of dairy cattle health and management practices in the United States, 2007 (Info Sheet 4p, October, 2008). 2008. Available online: https://www.aphis.usda.gov/animal_health/nahms/dairy/downloads/dairy07/Dairy07_ir_Food_safety.pdf (accessed on 23 March 2020).

5. Vanderhaeghen, W.; Piepers, S.; Leroy, F.; Van Coillie, E.; Haesebrouck, F.; De Vliegher, S. Invited review: Effect, persistence, and virulence of coagulase-negative Staphylococcus species associated with ruminant udder health. J. Dairy Sci. 2014, 97, 5275-5293. [CrossRef] [PubMed]

6. Taponen, S.; Pyorala, S. Coagulase-negative staphylococci as cause of bovine mastitis- not so different from Staphylococcus aureus? Vet Microbiol. 2009, 134, 29-36. [CrossRef]

7. De Vliegher, S.; Fox, L.K.; Piepers, S.; McDougall, S.; Barkema, H.W. Invited review: Mastitis in dairy heifers: Nature of the disease, potential impact, prevention, and control. J. Dairy Sci. 2012, 95, 1025-1040. [CrossRef]

8. Nyman, A.K.; Fasth, C.; Waller, K.P. Intramammary infections with different non-aureus staphylococci in dairy cows. J. Dairy Sci. 2018, 101, 1403-1418. [CrossRef]

9. De Vliegher, S.; Opsomer, G.; Vanrolleghem, A.; Devriese, L.; Sampimon, O.; Sol, J.; Barkema, H.; Haesebrouck, F.; de Kruif, A. In vitro growth inhibition of major mastitis pathogens by Staphylococcus chromogenes originating from teat apices of dairy heifers. Vet. Microbiol. 2004, 101, 215-221. [CrossRef]

10. Bradley, A.J. Bovine mastitis: An evolving disease. Vet. J. 2002, 164, 116-128. [CrossRef]

11. Drackley, J.K. ADSA Foundation Scholar Award. Biology of dairy cows during the transition period: The final frontier? J. Dairy Sci. 1999, 82, 2259-2273.

12. Esposito, G.; Irons, P.C.; Webb, E.C.; Chapwanya, A. Interactions between negative energy balance, metabolic diseases, uterine health and immune response in transition dairy cows. Anim. Reprod. Sci. 2014, 144, 60-71. [CrossRef]

13. Pinedo, P.J.; Fleming, C.; Risco, C.A. Events occurring during the previous lactation, the dry period, and peripartum as risk factors for early lactation mastitis in cows receiving 2 different intramammary dry cow therapies. J. Dairy Sci. 2012, 95, 7015-7026. [CrossRef] [PubMed]

14. Erskine, R.J.; Eberhart, R.J.; Scholz, R.W. Experimentally induced Staphylococcus aureus mastitis in selenium-deficient and selenium-supplemented dairy cows. Am. J. Vet. Res. 1990, 51, 1107-1111. [PubMed]

15. Newbould, F.H.S. Evaluation of induced infections as a research method. J. Am. Vet. Med. Assoc. 1977, 170, 1208-1209. [PubMed]

16. Schukken, Y.H.; Leslie, K.E.; Barnum, D.A.; Mallard, B.A.; Lumsden, J.H.; Dick, P.C.; Vessie, G.H.; Kehrli, M.E. Experimental Staphylococcus aureus intramammary challenge in late lactation dairy cows: Quarter and cow effects determining the probability of infection. J. Dairy Sci. 1999, 82, 2393-2401. [CrossRef]

17. Enger, B.D.; Crutchfield, C.E.; Yohe, T.T.; Enger, K.M.; Nickerson, S.C.; Parsons, C.L.M.; Akers, R.M. Staphylococcus aureus intramammary challenge in non-lactating mammary glands stimulated to rapidly grow and develop with estradiol and progesterone. Vet. Res. 2018, 49, 47. [CrossRef] [PubMed]

18. Kerro-Dego, O.; Prysliak, T.; Perez-Casal, J.; Potter, A.A. Role of GapC in the pathogenesis of Staphylococcus aureus. Vet. Microbiol. 2012, 156, 443-447. [CrossRef] [PubMed]

19. Concha, C.; Holmberg, O.; Morein, B. Proportion of B- and T-lymphocytes in normal bovine milk. J. Dairy Res. 1978, 45, 287-290. [CrossRef]

20. Ezzat Alnakip, M.; Quintela-Baluja, M.; Bohme, K.; Fernandez-No, I.; Caamano-Antelo, S.; Calo-Mata, P.; Barros-Velazquez, J. The Immunology of Mammary Gland of Dairy Ruminants between Healthy and Inflammatory Conditions. J. Vet. Med. 2014, 2014, 659801. [CrossRef]

21. Oliver, S.; Gonzalez, R.; Hogan, J.; Jayarao, B.; Owens, W. Microbiological Procedures for the Diagnosis of Bovine udder Infection and Determination of Milk Quality; National Mastitis Council: Verona WI, USA, 2004.

22. McDougal, L.K.; Steward, C.D.; Killgore, G.E.; Chaitram, J.M.; McAllister, S.K.; Tenover, F.C. Pulsed-field gel electrophoresis typing of oxacillin-resistant Staphylococcus aureus isolates from the United States: Establishing a national database. J. Clin. Microbiol. 2003, 41, 5113-5120. [CrossRef]

23. Abdi, R.D.; Gillespie, B.E.; Vaughn, J.; Merrill, C.; Headrick, S.I.; Ensermu, D.B.; D’Souza, D.H.; Agga, G.E.; Almeida, R.A.; Oliver, S.P.; et al. Antimicrobial Resistance of Staphylococcus aureus Isolates from Dairy Cows and Genetic Diversity of Resistant Isolates. Foodborne Pathog. Dis. 2018, 15, 449-458. [CrossRef] 
24. Kerro Dego, O.; Prysliak, T.; Potter, A.A.; Perez-Casal, J. DNA-protein immunization against the GapB and GapC proteins of a mastitis isolate of Staphylococcus aureus. Vet. Immunol. Immunopathol. 2006, 113, 125-138. [CrossRef] [PubMed]

25. Boerhout, E.M.; Koets, A.P.; Vernooij, J.C.M.; Mols-Vorstermans, T.G.T.; Nuijten, P.J.M.; Rutten, V.; Bijlsma, J.J.E.; Eisenberg, S.W.F. Reisolation of Staphylococcus aureus from bovine milk following experimental inoculation is influenced by fat percentage and specific immunoglobulin G1 titer in milk. J. Dairy Sci. 2016, 99, 4259-4269. [CrossRef] [PubMed]

26. Bannerman, D.D.; Paape, M.J.; Chockalingam, A. Staphylococcus aureus intramammary infection elicits increased production of transforming growth factor-alpha, beta1, and beta2. Vet. Immunol. Immunopathol. 2006, 112, 309-315. [CrossRef] [PubMed]

27. Eckersall, P.D.; Young, F.J.; Nolan, A.M.; Knight, C.H.; McComb, C.; Waterston, M.M.; Hogarth, C.J.; Scott, E.M.; Fitzpatrick, J.L. Acute phase proteins in bovine milk in an experimental model of Staphylococcus aureus subclinical mastitis. J. Dairy Sci. 2006, 89, 1488-1501. [CrossRef]

28. Petzl, W.; Zerbe, H.; Gunther, J.; Yang, W.; Seyfert, H.M.; Nurnberg, G.; Schuberth, H.J. Escherichia coli, but not Staphylococcus aureus triggers an early increased expression of factors contributing to the innate immune defense in the udder of the cow. Vet. Res. 2008, 39, 18. [CrossRef]

(C) 2020 by the authors. Licensee MDPI, Basel, Switzerland. This article is an open access article distributed under the terms and conditions of the Creative Commons Attribution (CC BY) license (http://creativecommons.org/licenses/by/4.0/). 